\title{
SISTEM PENUNJANG KEPUTUSAN PADA SOLUSI PENERIMAAN BEASISWA BAGI MAHASISWA MENGGUNAKAN FUZZY MAMDANI
}

\author{
Ida Fitriani \\ Teknik Informatika, Universitas Indraprasta PGRI \\ idafitriani2604@gmail.com
}

\begin{abstract}
Abstrak
Universitas Nasional merupakan salah satu perguruan tinggi swasta yang berada di Jakarta Selatan yang setiap tahun selalu memberikan program beasiswa kepada mahasiswa yang pantas mendapatkan beasiswa. Beasiswa diberikan sebagai pendukung atau apresiasi terhadap mahasiswa yang berprestasi dan yang kurang mampu. Pada cara sederhana, nilai dari setiap siswa dan bobot kriteria kurang diperhatikan, sehingga hasil yang diperoleh kurang mewakili dari nilai tersebut. Proses seleksi penerimaan beasiswa memerlukan suatu sistem terkomputerisasi yang dapat menunjang pengambilan keputusan. Pada penelitian ini dibangun sistem penunjang keputusan menggunakan logika fuzzy dengan metode mamdani. Penerapan metode fuzzy mamdani diterapkan pada sistem yang dibuat dengan bantuan tool box fuzzy program Matlab. Terdapat beberapa kriteria yang menjadi dasar pengambilan keputusan untuk seleksi penerimaan beasiswa, yaitu IPK, Semester, Penghasilan Orang Tua, Tunjangan Orang Tua, Usia, dan Piagam. Hasil seleksi yang diberikan kepada mahasiswa berupa jenis beasiswa yang dapat diterima oleh mahasiswa yang bersangkutan. Penilaian dilakukan dengan memberikan nilai bobot untuk setiap variabel dari masing-masing kriteria. Proses seleksi dengan metode mamdani menghasilkan mahasiswa yang pantas mendapatkan beasiswa atau tidak dan merekomendasikan jenis beasiswa yang dapat diperoleh mahasiswa untuk mendapatkan beasiswa.
\end{abstract}

Kata Kunci : SPK, Fuzzy MADM, Mamdani, Matlab

\begin{abstract}
Universitas Nasional is one of the private universities located in South Jakarta. It offers scholarship programs every year to students who deserve a scholarship. Scholarships are awarded as a support or appreciation for outstanding and underprivileged students. In a traditional way, the scores of each student and the criterion's weight just get little attention, causing the obtained results does not fully represent the scores. The selection process of scholarship award requires a computerized system that can support the decision-making. In this study, a decision support system is built using fuzzy logic with mamdani method. The fuzzy mamdani method is applied to the system created with the help of the Matlab program fuzzy tool box. There are some criteria used as the basis for decision-making for selection of scholarship award, i.e. GPA, Semester, Parent's Income, Parent's Allowance, Age, and Certificate. The results of the selection given to the students are in the form of scholarships that can be won by the related students. The assessment is conducted by scoring each variable of each criterion. The selection process using the mamdani method shows whether the students deserve a scholarship or not and recommends the type of scholarships that can be earned by the students obtaining the scholarships.
\end{abstract}

Keywords : SPK, Fuzzy MADM, Mamdani, Matlab

\section{PENDAHULUAN}

Beasiswa adalah bentuk penghargaan yang diberikan kepada individu agar dapat melanjutkan pendidikan ke jenjang yang lebih tinggi. Penghargaan itu dapat berupa akses tertentu pada suatu institusi atau penghargaan berupa bantuan keuangan. Bantuan ini biasanya berbentuk dana untuk 289 menunjang biaya atau dana pengganti yang harus dikeluarkan oleh anak sekolah atau mahasiswa selama menempuh masa pendidikan [1]. Beasiswa bagi mahasiswa merupakan suatu media motivasi untuk mengembangkan prestasi baik dalam segi akademik maupun sosial. Selain itu beasiswa juga membantu orang tua dalam Ida Fitriani, Sistem Penunjang Keputusan ... 
meringankan beban biaya pendidikan terutama bagi seseorang yang kurang mampu.

Beasiswa di lingkungan Fakultas Teknologi Komunikasi dan Informatika, Universitas Nasional selain bertujuan untuk menciptakan generasi baru yang lebih pintar dan cerdas, juga memiliki tujuan untuk menciptakan pemerataan suatu ilmu pengetahuan atau pendidikan kepada setiap orang yang membutuhkan, serta meningkatkan kesejahteraan.

Aplikasi yang ada di Universitas Nasional sampai sekarang, hanya mampu menangani data yang bersifat pasti. Sedangkan ketika menentukan mahasiswa yang layak untuk direkomendasikan mendapat beasiswa merupakan salah satu kondisi yang memiliki nilai yang samar, tidak pasti, atau ambigu. Pada proses perekomendasian beasiswa, tentunya ada kriteria-kriteria yang harus dipenuhi oleh mahasiswa. Apabila jumlah mahasiswa yang mendaftar sebagai penerima beasiswa relatif sedikit, maka proses perekomendasian untuk beasiswa yang ditawarkan tidak begitu rumit, namun proses ini akan sangat menyita waktu dan tenaga apabila data mahasiswa yang harus dianalisa cukup besar. Dalam hal ini selain masalah efisiensi, maka peluang terjadinya kesalahan akan semakin besar apabila dilakukan secara manual.

Pada penelitian sebelumnya tentang sistem penunjang keputusan pemilihan penerima beasiswa, metode yang digunakan dalam sistem pendukung keputusan penetapan rangking penerima beasiswa tersebut adalah Analytical Hierarchy Process (AHP) [2]. Konsep AHP yang penulis terdahulu gunakan yaitu mengubah nilainilai kualitatif menjadi nilai kuantitatif. Harapannya agar keputusan-keputusan yang diambil bisa lebih obyektif dan lebih cepat [3]. Pada penelitian ini penulis melakukan penelitian yang sama, namun dengan pendekatan logika fuzzy mamdani 290 dengan hasil akhir sistem pendukung keputusan yang dapat merekomendasikan atau tidak merekomendasikan mahasiswa untuk menerima beasiswa dan merekomendasikan jenis beasiswa yang dapat diterima oleh mahasiswa. Kriteria yang ditetapkan dalam studi kasus ini adalah nilai Indeks Prestasi Akademik (IPK), semester, penghasilan orang tua, tanggungan orang tua, usia, dan piagam.

Berdasarkan pada permasalahan yang telah dipaparkan, maka fokus penelitian ini adalah Sistem Penunjang Keputusan Pada Solusi Penerimaan Beasiswa Bagi Mahasiswa Menggunakan Fuzzy Mamdani.

\section{Logika Fuzzy Mamdani}

Logika fuzzy merupakan salah satu komponen pembentuk soft computing. Logika fuzzy pertama kali diperkenalkan oleh Prof. Lotfi A. Zadeh pada tahun 1965 [4]. Dasar logika fuzzy adalah teori himpunan fuzzy. Pada teori himpunan fuzzy, peranan derajat keanggotaan sebagai penentu keberadaan elemen dalam suatu himpunan sangatlah penting. Nilai keanggotaan atau derajat keanggotaan atau membership function menjadi ciri utama dari penalaran dengan logika fuzzy tersebut [10].

Ada tiga proses utama jika ingin mengimplementasikan fuzzy logic pada suatu perangkat, yaitu fuzzifikasi, rule, dan defuzzifikasi.

Ida Fitriani, Sistem Penunjang Keputusan ... 


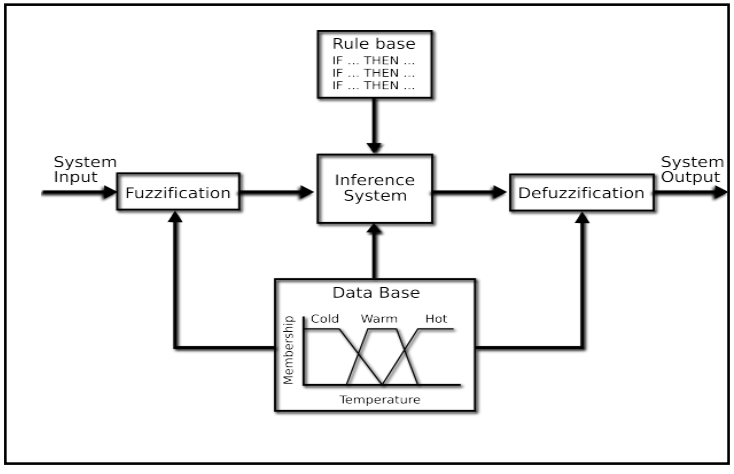

Sumber : Perancangan Fuzzy

\section{Gambar 1. Alur Perancangan Logika} Fuzzy

Logika fuzzy mamdani merupakan salah satu metode yang sangat fleksibel dan memiliki toleransi pada data yang ada. Fuzzy mamdani memiliki kelebihan yakni, lebih intuitif, diterima oleh banyak pihak. Penggunaan fuzzy mamdani ini sama halnya dengan penggunaan metode peramalan pada bidang statistik [5]. Penentuan analisis berdasarkan pendekatan fuzzy lebih efisien dalam pendekatan menggunakan angka dibanding dengan metode peramalan. Peramalan dalam statistik dapat menghasilkan error lebih besar dari pendekatan fuzzy. Dengan melakukan pendekatan fuzzy menghasilkan out put yang lebih dekat dengan keadaan sebenarnya [6].

Metode mamdani sering dikenal sebagai metode Max-Min. metode ini diperkenalkan oleh Ebrahim Mamdani tahun 1975 [7]. Untuk mendapatkan output, diperlukan 4 tahapan:

1. Pembentukan himpunan fuzzy

Pada metode mamdani, baik variable input maupun variable output dibagi menjadi satu atau lebih himpunan fuzzy.

2. Aplikasi fungsi implikasi (aturan)

Pada metode mamdani, fungsi implikasi yang digunakan adalah min

3. Komposisi aturan

Ada tiga metode yang digunakan dalam melakukan inferensi system fuzzy, yaitu max, additive dan probabilistic OD (probor)

291

\section{Penegasan (defuzzy)}

Input dari proses defuzzy adalah suatu himpunan fuzzy yang diperoleh dari komposisi aturan - aturan fuzzy, sedangkan output yang dihasilkan merupakan suatu bilangan pada domain himpunan fuzzy tersebut, Sehingga jika diberikan suatu himpunan fuzzy dengan range tertentu, maka harus dapat diambil suatu nilai crisp tertentu sebagai output. Ada beberapa metode defuzzy yang biasa digunakan pada komposisi aturan mamdani, yaitu centroid, bosektor, mean of maximum, largest of maximum dan smallest of maximum.

\section{Tujuan Penelitian}

Tujuan penelitian ini adalah merancang dan mengimplementasi aplikasi beasiswa untuk menentukan seleksi penerimaan beasiswa bagi mahasiswa menggunakan fuzzy mamdani

\section{Manfaat Penelitian}

Penelitian ini diharapkan dapat memberikan manfaat bagi akademik dan peneliti sendiri. Dari segi manfaat bagi akademik diharapkan dengan menggunakan sistem informasi beasiswa ini, dalam menen tukan penerimaan beasiswa dapat dilakukan lebih cepat dan transparan. Begitu pula bagi peneliti sendiri berharap dengan hasil ini dapat meningkatkan pemahaman peniliti mengenai pengelolaan beasiswa.

\section{METODE PENELITIAN}

Penelitian pertama dilakukan dengan melakukan studi literatur mengenai beasiswa di lingkungan Universitas Nasional yaitu di Fakultas Teknologi Komunikasi dan Informatika, dengan melakukan studi literatur, penulis mendapatkan informasi mengenai info beasiswa yaitu mengenai masalah masalah yang sedang dihadapi berkaitan dengan penerimaan beasiswa, syarat syarat beasiswa, jenis beasiswa dan Ida Fitriani, Sistem Penunjang Keputusan ... 
ketentuan - ketentuan yang berkaitan dengan penerimaan beasiswa. Gambar 2 merupakan tahapan penelitian dalam pembuatan aplikasi penerimaan beasiswa menggunakan metode fuzzy mamdani.

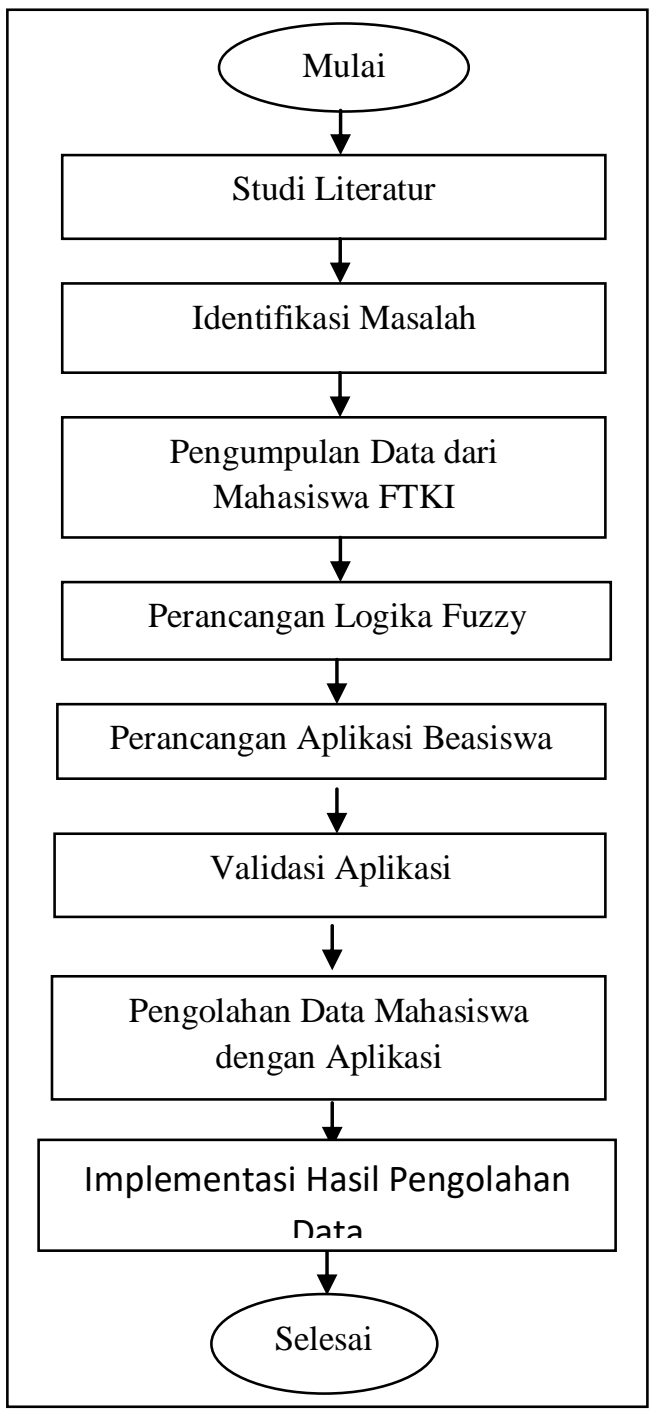

Gambar 2. Tahapan Penelitian

\section{Jenis Beasiswa}

Jenis beasiswa yang ditawarkan Universitas Nasional adalah beasiswa Bantuan Biaya Pendidikan Peningkatan Prestasi Akademik (BBP-PPA), Beasiswa Peningkatan Prestasi Akademik (B-PPA) dan Beasiswa Djarum, namun apabila mahasiswa yang mengajukan beasiswa tidak memenuhi persyaratannya, maka mahasiswa tersebut tidak mendapatkan beasiswa. Tabel 1 merupakan tabel beasiswa yang telah dikonversikan dengan bilangan fuzzy.

\section{Tabel 1. Beasiswa}

\begin{tabular}{|c|c|}
\hline Beasiswa & Nilai \\
\hline Tidak mendapatkan beasiswa & 0 \\
\hline BBP-PPA & 2.5 \\
\hline B-PPA & 5 \\
\hline Beasiswa Djarum & 10 \\
\hline
\end{tabular}

\section{Persyaratan Penerimaan Beasiswa}

Mahasiswa mendapatkan beasiswa jika memenuhi persyaratan yang dibutuhkan. Berikut merupakan persyaratan yang dibutuhkan untuk pengambilan keputusan penerimaan beasiswa dan tabel interval yang telah dikonversikan dengan bilangan fuzzy.

Tabel 2. Nilai IPK

\begin{tabular}{|c|c|}
\hline Nilai IPK & Nilai \\
\hline IPK $<2.75$ & 0 \\
\hline $2.75 \leq \mathrm{IPK}<3$ & 5 \\
\hline $3 \leq \mathrm{IPK} \leq 4$ & 10 \\
\hline
\end{tabular}

Tabel 3. Semester

\begin{tabular}{|c|c|}
\hline Semester & Nilai \\
\hline semester $\leq 2$ & 0 \\
\hline $2<$ semester $\leq 4$ & 5 \\
\hline $4<$ semester $<8$ & 10 \\
\hline
\end{tabular}

Ida Fitriani, Sistem Penunjang Keputusan ... 
Tabel 4. Penghasilan Orang Tua

\begin{tabular}{|c|c|}
\hline Penghasilan Orang Tua & Nilai \\
\hline penghasilan orang tua $>$ Rp. 3.500.000,- & 0 \\
\hline $\begin{array}{c}\text { Rp. } 2.500 .000,-<\text { penghasilan orang tua } \leq \\
\text { Rp. 3.500.000,- }\end{array}$ & 5 \\
\hline penghasilan orang tua $\leq$ Rp. $2.500 .000,-$ & 10 \\
\hline
\end{tabular}

Tabel 5.Tanggungan Orang Tua

\begin{tabular}{|c|c|}
\hline Tanggungan Orang Tua & Nilai \\
\hline tanggungan orang tua $\leq 2$ & 0 \\
\hline $2<$ tanggungan orang tua $\leq 5$ & 5 \\
\hline tanggungan orang tua $>5$ & 10 \\
\hline
\end{tabular}

Tabel 6. Usia

\begin{tabular}{|c|c|}
\hline Usia & Nilai \\
\hline 17 tahun $\leq$ Usia $\leq 18$ tahun & 0 \\
\hline 19 tahun $\leq$ Usia $\leq 20$ tahun & 5 \\
\hline 21 tahun $\leq$ Usia $\leq 23$ tahun & 10 \\
\hline
\end{tabular}

Tabel 7.Piagam

\begin{tabular}{|l|c|}
\hline \multicolumn{1}{|c|}{ Piagam } & Nilai \\
\hline Tidak mempunyai piagam & 0 \\
\hline Piagam tingkat regional / nasional & 5 \\
\hline Piagam juara internasional & 10 \\
\hline
\end{tabular}

\section{HASIL DAN PEMBAHASAN} Analisis Kebutuhan

Kebutuhan informasi merupakan kebutuhan yang diperlukan untuk pembuatan aplikasi. Kriteria yang dibutuhkan untuk pengambilan keputusan berdasarkan persyaratan beasiswa yaitu kriteria Nilai IPK, Semester, Penghasilan Orang Tua, Tanggungan Orang Tua, Usia dan Piagam. Nilai ini didapat ketika penulis melakukan wawancara kepada pihak biro kemahasiswaan Universitas Nasional bahwa ternyata nilai tersebutlah yang mempengaruhi dalam penerimaan beasiswa di lingkungan Fakultas Teknologi Komunikasi dan Informatika, Universitas Nasional. Sedangkan nilai keluarannya berupa beasiswa.

\section{Perancangan Logika Fuzzy}

Perancangan logika fuzzy diawali dengan pembuatan membership function untuk tiap - tiap variabel input kemudian dibuatkan rumusan aturan. Aturan tersebut digunakan untuk merumuskan beasiswa yang tepat diperoleh mahasiswa yang mendaftar seleksi penerimaan beasiswa. Aturan penerimaan beasiswa menggunakan operator AND, yaitu if... and...then... Operator $A N D$ merupakan operator yang tepat karena dalam penerimaan beasiswa terdapat 6 variabel input yaitu dengan 18 himpunan fuzzy yang nantinya dari 18 himpunan fuzzy tersebut dibuat suatu aturan sehingga dapat menghasilkan output yang maksimal. Oleh karena itu dapat disimpulkan bahwa aturan yang digunakan dalam merancang logika fuzzy penerimaan beasiswa yaitu If (IPK) and (SEMESTER) and (PENGHASILAN ORANG TUA) and (TANGGUNGAN) and (USIA) and (PIAGAM) then (BEASISWA). Tabel 4.1 merupakan tabel yang digunakan untuk membuat aturan dalam fuzzy logic (aturannya terdapat pada lampiran).

\section{Perancangan Aturan Logika fuzzy}

Jika Input IPK $<2.75$ dan Semester 1-2 dan Penghasilan Orang Tua $>3.500 .000$ dan Tanggungan Orang Tua 1-2 Orang dan Usia 17-18 tahun dan Piagam Tidak Ada maka Output Beasiswanya Tidak Mendapatkan Beasiswa.Jika Input IPK 2.75 - 3.00 dan Semester 3-4 dan Penghasilan Orang Tua 2.500.000 3.500.000 dan Tanggungan Orang Tua 3-5 Orang dan Usia 19-20 tahun dan mempunyai piagam Regional/Nasional maka Output Beasiswanya BBP-PPA. Jika Input IPK 3.00 - 4.00 dan Semester 5-7 dan Penghasilan Orang Tua $<2.500 .000$ dan Tanggungan Orang Tua $>5$ Orang dan Usia 21-23 tahun dan mempunyai piagam internasional maka Output Beasiswanya BPPA atau Beasiswa Djarum.

Dari perancangan aturan logika fuzzy maka dibuatkan rule editor pada fuzzy logic sehingga dapat menghasilkan ouput jenis beasiswa. Gambar 3 di bawah ini

Ida Fitriani, Sistem Penunjang Keputusan ... 
merupakan rule editor dari aplikasi beasiswa.

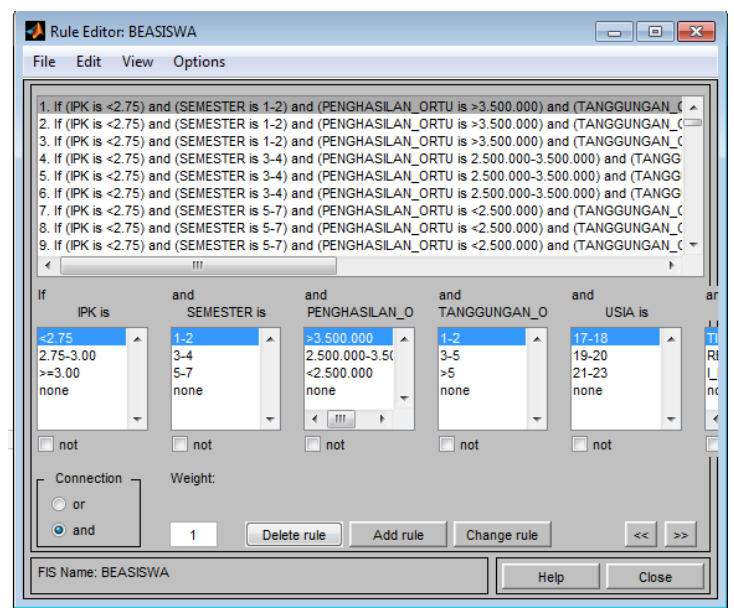

Gambar 3. Rule Editor Beasiswa

\section{Hasil Running Program Aplikasi Beasiswa}

Tampilan awal ketika menjalankan aplikasi ini adalah tampilan 'Menu Login. Untuk menjalankan 'Menu Login', admin memasukkan password yang sebelumnya telah ditentukan. Gambar 4 merupakan hasil running "Menu Login"

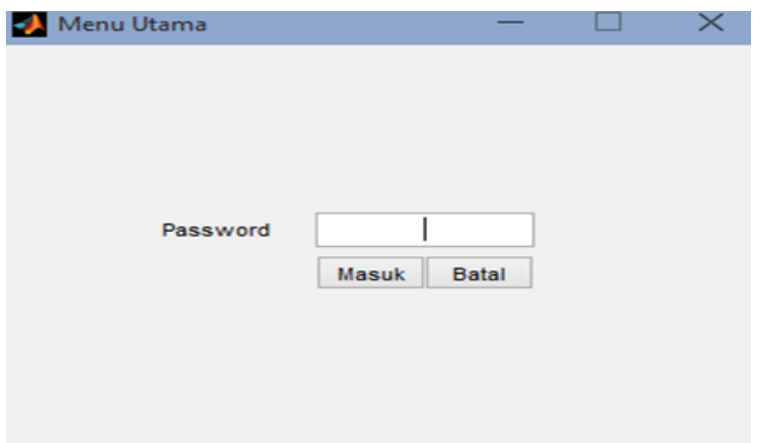

\section{Gambar 4. Tampilan'Menu Login'}

Pada menu tersebut terdapat dua button, yaitu button 'Masuk' dan button 'Batal'. Button 'Masuk' digunakan apabila admin ingin menggunakan aplikasi dengan sebelumnya mengisi password terlebih dahulu. Button 'Batal' digunakan apabila admin ingin membatalkan perintah untuk login. Apabila admin memasukkan password yang salah, maka aplikasi akan menginformasikan bahwa password yang admin masukkan salah. Gambar 5 merupakan tampilan menu pemberitahuan jika admin salah memasukkan password.

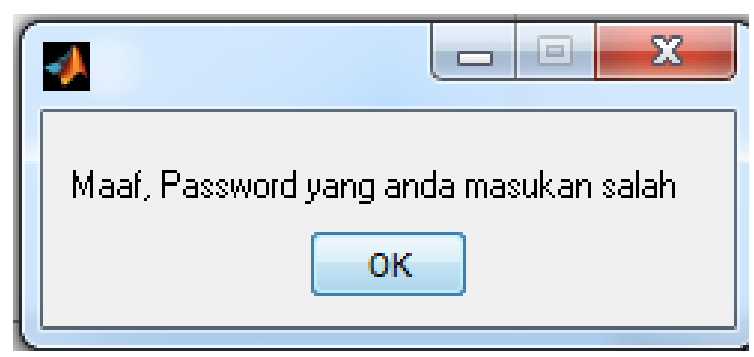

\section{Gambar 5. Tampilan Menu Salah} Password

Setelah admin menginputkan password dan memilih button 'Mulai', maka akan muncul tampilan menu 'Data Mahasiswa'. Gambar 6 merupakan hasil running menu 'Data Mahasiswa'.

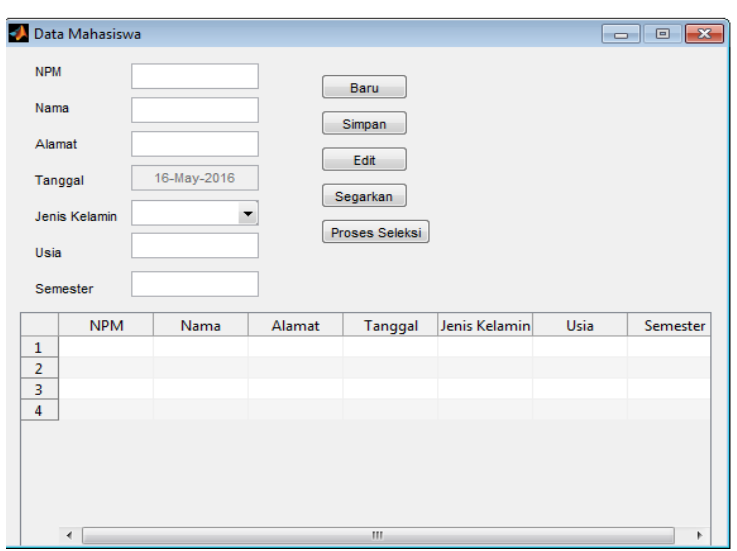

Gambar 6. Tampilan Menu 'Data Mahasiswa'

Pada menu 'Data Mahasiswa', admin dapat memasukkan data mahasiswa yang baru, mengedit, menghapus dan melakukan seleksi penerimnaan beasiswa. Hapus data mahasiswa terdapat pada menu edit. Admin dapat memilih button 'Baru' untuk mengisi data mahasiswa. Pada menu 'Data Mahasiswa' admin memasukkan data mahasiswa seperti NPM, nama, alamat, jenis kelamin, usia dan semester, kemudian setelah data terisi, admin memilih button 'Simpan' dan data mahasiswa yang telah dimasukkan akan tersimpan di database. Admin juga dapat mengedit dan menghapus data mahasiswa dengan memilih button 'Edit'.

Ida Fitriani, Sistem Penunjang Keputusan ... 
Pada menu 'Edit Data Mahasiswa' terdapat button 'Edit'. Untuk mengedit data mahasiswa, admin dapat memasukkan NPM mahasiswa yang akan diedit kemudian admin memilih button 'Periksa' untuk menampilkan data mahasiswa, setelah datanya diedit, admin dapat memilih button 'Update'. Gambar 7 merupakan tampilan menu 'Edit Data Mahasiswa' Button 'Édit'

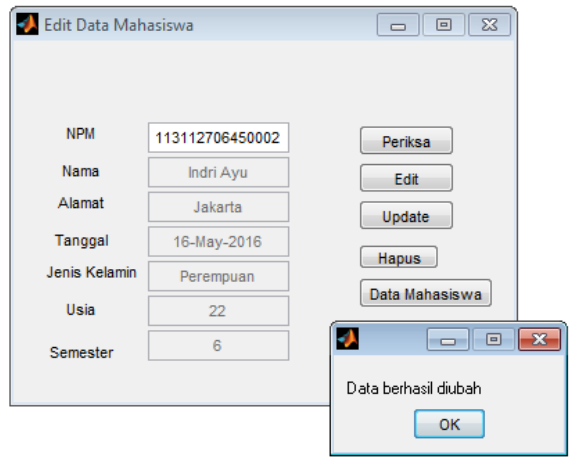

\section{Gambar 7. Tampilan Menu 'Edit Data} Mahasiswa'Button 'Édit'

Pada menu 'Edit Data Mahasiswa', terdapat juga button 'Hapus' untuk menghapus data mahasiswa yang sebelumnya sudah tersimpan. Gambar 8 merupakan tampilan menu 'Edit Data Mahasiswa.

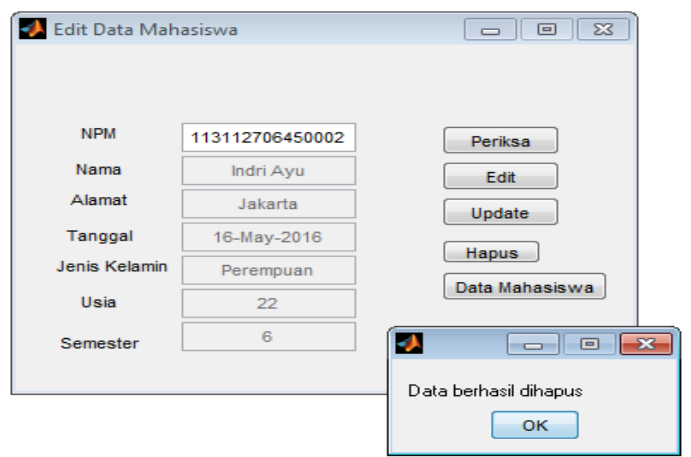

Gambar 8. Tampilan Menu 'Edit Data Mahasiswa Button 'Hapus

Admin dapat memasukkan NPM mahasiswa yang akan dihapus kemudian admin memilih button 'Periksa' untuk menampilkan data mahasiswa yang akan dihapus setelah itu admin dapat memilih button 'Hapus' dan data mahasiswa akan terhapus dalam database.
Data mahasiswa yang telah tersimpan dalam database dapat dilakukan penyeleksian dengan memilih button 'Proses Seleksi' pada 'Menu Data Mahasiswa. Pada menu 'Seleksi Beasiswa' admin dapat menyeleksi mahasiswa yang akan mendapatkan beasiswa yaitu dengan memasukkan NPM terlebih dahulu dan data mahasiswa. Gambar 9 merupakan hasil running menu 'Seleksi Beasiswa'

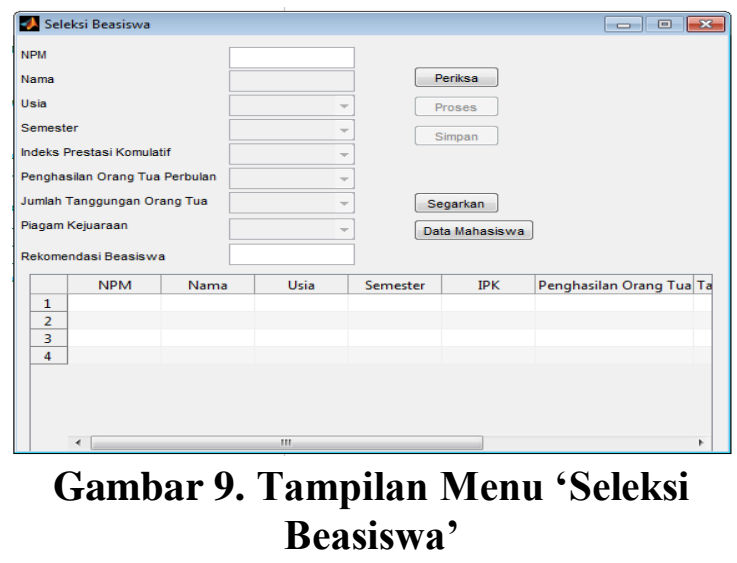

Pada menu 'Proses Seleksi' beasiswa, admin terlebih dahulu memasukkan data NPM mahasiswa yang akan diseleksi, kemudian admin dapat memilih button 'Periksa' untuk memverifikasi nama mahasiswa yang sebelumnya telah diinput dan tersimpan di database. Setelah NPM dan nama mahasiswa sesuai, selanjutnya admin dapat mengisi data pada kolom usia, semester, nilai IPK, penghasilan orang tua, jumlah tanggungan dan piagam kejuaraan dengan memilih pada list masing - masing kolom. Setelah data semuanya terisi, admin dapat memilih Button 'Proses' untuk memproses seleksi penerimaan beasiswa dan jenis beasiswa yang layak dimiliki mahasiswa itu pun akan muncul di kolom rekomendasi beasiswa.

Ida Fitriani, Sistem Penunjang Keputusan ... 
Hasil Pengujian Aplikasi Beasiswa Terhadap Data Mahasiswa

\begin{tabular}{|c|c|}
\hline Pengujian & $\begin{array}{l}\text { Pengujian Beasiswa } \\
\text { B-PPA }\end{array}$ \\
\hline Skenario & $\begin{array}{l}\text { Khairunnisa } \\
\text { Nurwulansari mendaftar } \\
\text { untuk mendapatkan } \\
\text { beasiswa dengan kriteria } \\
\text { usia mahasiswa } 21 \text { tahun, } \\
\text { semester 6, IPK lebih } \\
\text { dari } 3 \text {, penghasilan orang } \\
\text { tua <2.500.000, jumlah } \\
\text { tanggungan orang tua }>5 \\
\text { orang dan tidak } \\
\text { mempunyai piagam } \\
\text { organisasi/ kejuaraan }\end{array}$ \\
\hline $\begin{array}{l}\text { Hasil yang } \\
\text { diharapkan }\end{array}$ & $\begin{array}{l}\text { Menampilkan proses } \\
\text { penerimaan beassiswa B- } \\
\text { PPA }\end{array}$ \\
\hline $\begin{array}{l}\text { Hasil } \\
\text { pengujian }\end{array}$ & 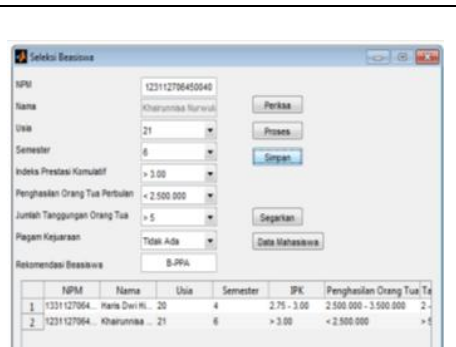 \\
\hline Keterangan & $\begin{array}{l}\text { Pengujian ini berhasil } \\
\text { dilakukan, Khairunnisa } \\
\text { Nurwulansari } \\
\text { mendapatkan beasiswa } \\
\text { B-PPA. }\end{array}$ \\
\hline
\end{tabular}

Tabel 9. Hasil Pengujian

Beasiswa BBP-PPA

\begin{tabular}{|c|c|}
\hline Pengujian & $\begin{array}{l}\text { Pengujian Beasiswa BBP- } \\
\text { PPA }\end{array}$ \\
\hline Skenario & $\begin{array}{l}\text { Haris Dwi Hidjracman } \\
\text { mendaftar } \\
\text { mendapatkan beasiswa } \\
\text { dengan kriteria usia } \\
\text { mahasiswa } 20 \text { tahun, } \\
\text { semester 4, IPK } 2.75- \\
3.00 \text {, penghasilan orang } \\
\text { tua } 2.500 .000-3.500 .000, \\
\text { jumlah tanggungan orang } \\
\text { tu 2-5 orang dan tidak } \\
\text { mempunyai piagam } \\
\text { organisasi/ kejuaraan }\end{array}$ \\
\hline $\begin{array}{l}\text { Hasil yang } \\
\text { diharapkan }\end{array}$ & $\begin{array}{lr}\text { Menampilkan } & \text { proses } \\
\text { penerimaan } & \text { beassiswa } \\
\text { BBP-PPA } & \end{array}$ \\
\hline $\begin{array}{l}\text { Hasil } \\
\text { pengujian }\end{array}$ & 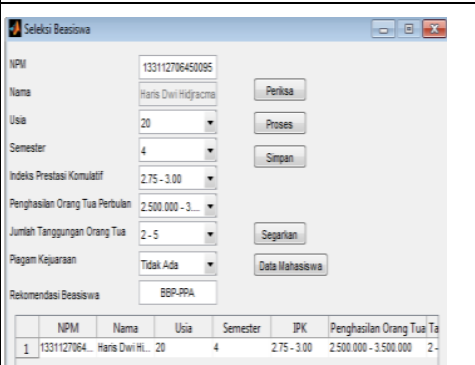 \\
\hline Keterangan & $\begin{array}{l}\text { Pengujian ini berhasil } \\
\text { dilakukan, Haris Dwi } \\
\text { Hidjracman mendapatkan } \\
\text { beasiswa BBP-PPA. }\end{array}$ \\
\hline
\end{tabular}


Tabel 10. Hasil Pengujian Beasiswa Djarum

\begin{tabular}{|c|c|}
\hline Pengujian & $\begin{array}{l}\text { Pengujian } \\
\text { Djarum }\end{array}$ \\
\hline Skenario & $\begin{array}{l}\text { Indri Ayu mendaftar } \\
\text { untuk mendapatkan } \\
\text { beasiswa dengan kriteria } \\
\text { usia mahasiswa } 22 \text { tahun, } \\
\text { semester 6, IPK lebih } \\
\text { dari 3.00, penghasilan } \\
\text { orang tua < } 2.500 .000 \text {, } \\
\text { jumlah tanggungan orang } \\
\text { tua lebih dari } 5 \text { orang dan } \\
\text { mempunyai piagam } \\
\text { organisasi/ kejuaraan }\end{array}$ \\
\hline $\begin{array}{l}\text { Hasil yang } \\
\text { diharapkan }\end{array}$ & 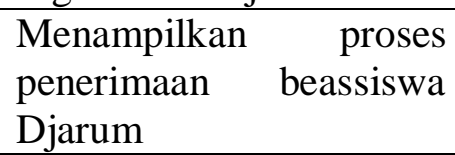 \\
\hline $\begin{array}{l}\text { Hasil } \\
\text { pengujian }\end{array}$ & 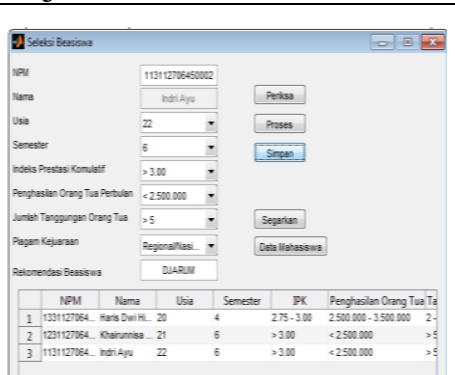 \\
\hline Keterangan & $\begin{array}{l}\text { Pengujian ini berhasil } \\
\text { dilakukan, Indri Ayu } \\
\text { mendapatkan beasiswa } \\
\text { Djarum }\end{array}$ \\
\hline
\end{tabular}

\section{Hasil Pengujian Tidak Mendapatkan Beasiswa}

Tabel 11. Pengujian Tidak Mendapatkan Beasiswa

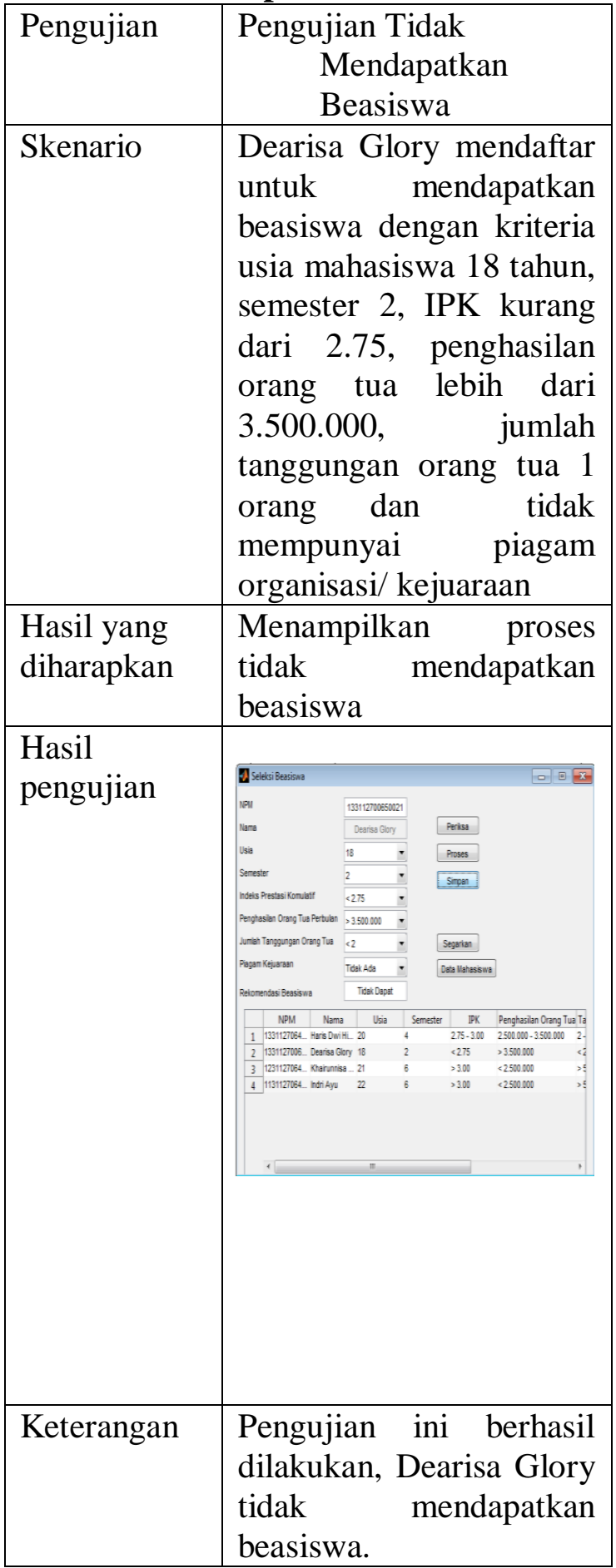

Berdasarkan hasil dari beberapa pengujian maka dapat ditarik kesimpulan bahwa aplikasi sudah berjalan sesuai dengan rancangan yang telah dibuat.

Ida Fitriani, Sistem Penunjang Keputusan ... 


\section{SIMPULAN}

Implementasi fuzzy mamdani pada penerimaan beasiswa bagi mahasiswa sudah dibangun. Penerapan metode fuzzy mamdani pada aplikasi ini dibuat dengan bantuan tool box fuzzy program Matlab. Penelitian dilakukan dengan memberikan nilai bobot untuk setiap variabel dari masing - masing kriteria. Kriteria yang menjadi dasar pengambilan keputusan untuk seleksi penerimaan beasiswa berupa IPK, Semester, Penghasilan Orang Tua, Tunjangan Orang Tua, Usia dan Piagam. Kemudian setelah itu dilakukan prosespenyeleksian dengan metode mamdani sehingga dapat merekomendasikan jenis beasiswa yang dapat diperoleh oleh mahasiswa tersebut.

\section{DAFTAR PUSTAKA}

[1] Purba, Kristo Radion. "Implementasi Logika Fuzzy Untuk Mengatur Perilaku Musuh Perilaku Musuh dalam Game Bertipe Action RPG".2013.

[2] Mustafidah, H. Dan Aryanto, D. "Sistem Inferensi Fuzzy untuk Memprediksi Prestasi Belajar Mahasiswa Berdasarkan Nilai Ujian Nasional, Tes Potensi Akademik, dan Motivasi Belajar”. JUITA. 2012

[3] Anshori, Yusuf. "Pendekatan Triangular Fuzzy Number dalam Metode Analytic Hierarchy Process". Palu, Universitas Tadulako. 2012.

[4] Wibowo, Henry., dkk. "Sistem Pendukung Keputusan untuk Menentukan Penerima Beasiswa Bank BRI Menggunakan FMDM". Yogyakarta, Universitas Islam Indonesia. 2009.

[5] Tri Dhanang, Sasongko. "Aplikasi Pendukung Keputusan Seleksi Penerimaan Beasiswa dengan Metode Fuzzy Tsukamoto”. Malang,
Universitas Muhammadiyah Malang. 2012.

[6] Manurung, Pangeran. "Sistem Pendukung Keputusan Seleksi Penerimaan Beasiswa dengan Metode AHP dan TOPSIS (Studi Kasus: FMIPA USU)". Medan, Universitas Sumatra Utara. 2010.

[7] Uyun Shofwatul, dan Imam Riadi. "A Fuzzy TOPSIS Multiple Attribute Decision Making for Scholarship Selection”. Yogyakarta, Universitas Islam Sunan Kalijaga dan Universitas Ahmad Dahlan. 2010.

[8] Kusumadewi, Sri., Sri Hartati, Agus Harjoko dan Retantyo W.,. "Fuzzy Multi - Attribute Decision Making (Fuzzy MADM)”. Yogyakarta : Graha Ilmu. 2006.

[9] Santoso, Djoyo. " Pedoman Beasiswa Peningkatan Prestasi Akademik (PPA) dan Bantuan Belajar Mahasiswa (BBM)". Jakarta. 2010.

[10] Kusumadewi, Sri dan Purnomo Hari. "Aplikasi Logika Fuzzy Untuk Pendukung Keputusan", Edisi 2. Yogyakarta: Graha Ilmu. 2010.

[11] Saaty. "Decision Making With Analytic Hierarchy Process". Int. J. Services Sciences, Vol. 1, No. 1. 2008.

[12] Jasril, Elin Haerani, IIs Afrianty. "Sistem Pendukung Keputusan (SPK) Pemilihan Karyawan Terbaik Menggunakan Metode Fuzzy AHP $(F-A H P)$ '. Yogyakarta, Universitas Islam Negeri Sultan Syarif Kasim Riau. 2011. 